\title{
Özdemir İnce'nin Şiir ve Gerçeklik Kitabı Üzerine
}

\section{PINAR ÇAKAR*}

zdemir İnce Şiir ve Gerçeklik adlı kitabının
içerisinde bulunan ve 1980'li yıllarda Varlık
dergisi başta olmak üzere dönemin çeşitli dergilerinde yayımlanan toplam on yedi eleştirel denemeden oluşan kaynak niteliğindeki kitabını okuyucularına sunmuştur.

Kitabın tanıtımına geçmeden önce şunu belirtmek gerekir

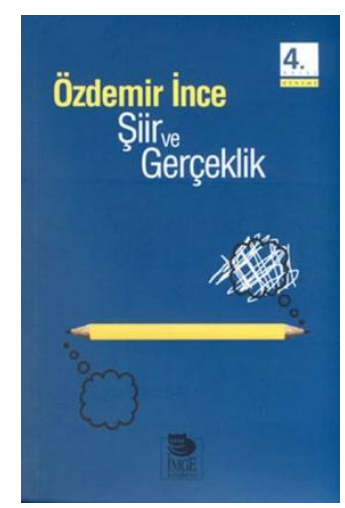
ki denemelerden oluşan bu kitaptaki yazılar önce şiir ve şair tanımları (ama daha çok şiir terimi ve kimliği üzerinde durulmuştur) verilerek belli bir sıra içerisinde imge, gerçeklik, dil ve anlam gibi başlıklarla bütünsellik sağlanarak tamamlanmıştır.

Kitap “İkinci Basıma Ön Söz” ve “Ön Söz” bölümleri ardından “Şiir İnsana Benzer" başlıklı deneme ile "Şairi şiir yazmaya çağıran şey nedir, kimdir?" gibi merak uyandıracak bir soruyla başlayıp sonrasında ikna edici cevaplarla devam edilip kaleme alınmıştır. Daha sonra "İmge ve Serüvenleri” başlıklı denemeye geçilerek imge, çeşitli tanım ve alıntılarla çağrışım yaptığı noktasında birleştirilmiş, örneklerle ve aşağıda verilen Özdemir İnce'nin kişisel görüşüyle devam etmiştir. “İmgeyi çok seviyorum. Çünkü şiirin bütün sorunlarıyla çok yakın ve sıcak bağları bulunduğunu, bir ozanın şiirine olduğu kadar, bir ülkenin şiirine damgasını vuran en önemli şiirsel etkilerden birinin imge olduğunu, şiirsel kimlik ve kişiliğin en vazgeçilmez ögesi sayılması gerektiğini düşünüyorum."

İlerleyen sayfalarda "Şiirsel Gerçek ve Boyutları" ve sonrasında da kitaba adını veren "Şiir ve Gerçeklik" adlı denemeye geçilmiş, şiir ve gerçekçilik arasındaki bağ, gerçeğin bir yandan eskirken diğer yandan da alan kazanıp genişlediğini göz önüne almamızın gerekliliği üzerinde durmuştur. Ardından şiirin aktarılması noktasında önemli araçların açıklandığı “Dil ve Anlam” başlıklı denemeye yer

* pinarcakar34 @gmail.com 
verilmiş, İlhan Berk'in kendisiyle yapılan bir söyleşide dil için söylediği düşüncelerine yer verilerek deneme oluşturulmuş ve sürdürülmüştür. “Benim hastalık kertesine varan bir yönüm var ki, o da dille yıkanmak, onunla gidip gelmektir. Böyle dillerle yıkana yıkana dilin alanında çukurlar kurmuşumdur. Bunlara batıp çıkma beni ürkütmemiştir." Yazının devam eden bölümlerinde ise dilin, bir yardımcı olmadığı düşüncenin vazgeçilmez ortağı olduğu gerçeği anlatılmış, dille ilgili çarpıcı bir benzetme kurularak durum somutlaştırılmıştır.

Özdemir İnce kitap içerisinde ilerleyen yazılarda "Gelenek Üzerine" tespit ve görüşlerine yer vermiş ve kitabın en dikkat çekici olduğuna inandığım denemesi olan "Sözcük, Dize, Çıkmaz ve Saçlar" bölümüne geçerek Cemal Süreya, Turgut Uyar ve Edip Cansever'in çeşitli dergilerde yazmış oldukları yazılar üzerine fikir ve tespitlerini eleştirel şekilde beyan etmiş; hem bilimsel hem de edebî olarak okuru tatmin etmiştir.

Kitabın sonlarına gelindiğinde ise "Siyasetnâme ve Tarihin Çağrısı" başlığıyla "Siyasetnâme" adını verdiği ve içinde uzunlu kısalı yetmiş altı şiirden oluştuğunu söylediği kitabını neden yazdığını anlatarak bir tanıtım yazısı bağlamında ve şiirin tarihle olan ilişkisini, tarih gelenek ilişkisi içerisinde anlatmıştır. Son olarak "Çağdaş Lirik Şiir Üzerine" adlı denemesi ile liriğin epik ve dramatik şiirden farkına değinmiş; lirik şiiri dönemsel bağlamda değerlendirip “çağdaş lirik ozan hem kendisi hem de başkası olabilen şairdir." sözüyle bu bütünleşmenin, lirik şiir türünün en önemli özelliği olduğunu söyleyip hem denemeyi hem de kitabı sonlandırmıştır.

İlk baskısı 1986 yılında yapılan Şiir ve Gerçeklik, Özdemir İnce'nin çeşitli konularla ilgili yazdığı denemelerden oluşturulan kitabıdır. Kitap içerisinde açıklanan kavramlar ve anlatılan durumlarla ilgili alanında ün salmış kişilerin görüşlerine yer verilmiştir. Özdemir İnce de kendi fikir ve tespitlerini eleştirel üslubuyla açıklayarak mantık kuralları çerçevesinde sağlam bir zemine oturtmuş ve okuyucunun zihnini saydamlaştırmıştır. Bu yönüyle yazımızın başında da söylediğimiz gibi alanında kaynak bir kitap oluşturmuştur. 